\title{
A Research Model of Consumers' Adoption and Continued Use of the Personally Controlled Electronic Health Record (PCEHR) System
}

\author{
Jun Xu, Xiangzhu Gao \& Golam Sorwar \\ Southern Cross Business School, Southern Cross University \\ Southern Cross Drive, Bilinga, Queensland 4225, Australia \\ Email: jun.xu@scu.edu.au
}

\begin{abstract}
Built on Xu and Quaddus's ${ }^{39}$ model of adoption and continued use of knowledge management systems, this paper develops a model of Australian consumers' adoption and use of the Personally Controlled Electronic Health Record (PCEHR) system. Factors and variables of the developed model are discussed in detail, and hypotheses arising from the proposed model are developed as well. The developed model has both empirical and practical implications. It can be adapted for e-health applications in various contexts and different countries.
\end{abstract}

Keywords: Adoption, Continued Use, PCEHR System, E-health, Australian Consumers.

\section{Introduction}

With the exponential growth of Internet penetration coupled with advances in technologies, the e-health movement has been introduced and accepted as an essential and important element in healthcare systems. The adoption of e-health initiatives is expected to bring a paradigm shift in traditional healthcare systems by reducing medical errors, enhancing healthcare quality, minimising healthcare costs, and empowering consumers to understand their healthcare needs and make informed decisions on their healthcare. As a health information source, electronic health records (EHRs) underpin all the other e-health initiatives. Meanwhile, according to Department of Health and Ageing ${ }^{17}$ on average, every year an Australian has "22 interactions with healthcare providers, including 4 visits to GPs, 12 prescriptions, 3 visits to specialists", and most of the information of these interactions has been held in paper-based files or non-shared databases. The medical information may be inconsistent between files, inaccurate because of lack of standards, incorrect because of manual operation, and is often not available in emergency situations. It is estimated that 5,000 Australians die each year due to adverse medical events;
$18 \%$ of medical errors in Australia occur from inadequate information; nearly $30 \%$ of unplanned hospital admissions are associated with prescription errors; and approximately $13 \%$ of healthcare provider consultations suffer missing information ${ }^{5,10,31}$. Patients may need to undergo the same tests with different healthcare providers. It is not unusual that the same questions are asked every time when patients deal with a different provider. A solution to these problems is electronic health records (i.e., the PCEHR system in Australia), which can include such information as the patient's prescribed medications, test results, care plans, immunisation records, health alerts, event summaries, discharge summaries, Medicare data, and personal data. Real-time and convenient access to such information will improve the quality of healthcare, especially in emergency situations and special conditions ${ }^{37}$.

It is widely believed in Australia the successful implementation of PCEHR system could provide great opportunities to improve the quality and safety of healthcare; reduce costs; improve continuity and health outcomes for patients; save lives, time, and money; make the Australian health system more efficient; and provide every Australian with equitable access to healthcare ${ }^{5,10}$. In addition, according to an estimate 
based on the economic modelling undertaken by Deloitte Consulting in 2010-2011, the PCEHR system could generate approximately $\$ 11.5$ billion in net direct benefits over the period of 2010 to 2025 , with $\$ 9.5$ billion to Australian governments and $\$ 2$ billion to the private sector including public hospitals, GPs, specialists, allied health clinics, private hospitals and private health insurance providers (Department of Health and Ageing ${ }^{17}$ ).

Even though the Australian government has invested significantly in deploying the PCEHR system and its associated infrastructure (including required technological infrastructure, standards, legislations, and others), but the system has not been well received by consumers (see $\mathrm{Xu}$ et al. $2012^{42}$ and $\mathrm{Xu}$ et al. $2013^{43}$ for discussion of some reported issues/concerns). The current release of the PCEHR system in Australia is far from mature and suffers criticisms from major stakeholders. The system is facing various challenges, and users are not enthusiastic in registering with and using the system. In addition, even in the recent PCEHR review ordered by the Federal government (the report was released in December 2013), the review panel members could have better representation from consumers, and many issues concerning individual users remain to be addressed. Consumer participation in the PCEHR system is essential for adoption and use of the system. At this stage, consumers have not been active in participation for different reasons and various concerns; and the interests of consumers may not have been properly represented in the development and implementation of the PCEHR system. For uncertain reasons, those activities by the National E-health Transition Authority (NEHTA) have not achieved the desired outcomes as evidenced by the current criticism and very low interest from potential system users (both individuals and health care providers).

In addition, there is a lack of comprehensive empirical studies of the current status and challenges/issues as well as the reasons and factors for success and failure of electronic health record systems, especially the PCEHR system. This study aims at addressing the gap via developing a model of adoption and continued use of the PCEHR system among Australian consumers by looking at two research questions:

- What are the factors influencing Australian consumers' decision to adopt the PCEHR system?
- What are the factors influencing Australian consumers' decision of continued use of the PCEHR system?

The outcomes of this research will go some way to answering concerns and issues associated with the PCEHR system and offer some insights and recommendation for significantly improving the efforts in deploying the system and bettering the efficiency of resources required for the implementation.

\section{Background}

$\mathrm{Xu}$ and Quaddus's ${ }^{39}$ model of Adoption and Continued Use of Knowledge Management Systems (KMSs) (see Figure 1) will be used as the basis to structure the model for individuals' adoption and continued use of the PCEHR system. The model is built on the theory of diffusion of innovations ${ }^{34}$, theory of reasoned action $(\mathrm{TRA})^{4}$, and technology acceptance model (TAM) ${ }^{12}$. These three theories are the primary theoretical foundations for many research projects on IT acceptance and use. While theory of diffusion of innovations focuses on the diffusion process of an innovation, TRA and TAM models attempt to explain the relationship between user attitudes, perceptions, beliefs, and actual use of a technology. Basically TRA and TAM suggest that some external factors influence the perceptions about a knowledge management system, which in turn affect the adoption of the innovation and lead to the use of the system, i.e. "External Factors" $>>$ "Views \& Perceptions" >> "Adoption Decision" (for pre-adoption stage) "Facilitating Condition/External Factors" $>>$ Realization of Benefits \& Consequences" $>$ "Continued Use" (for post-adoption stage). This simple model is generic in nature and is likely to be applicable, with some adjustments, in various innovation diffusion processes. This simple research model also serves as the conceptual framework for the development of the PCEHR adoption and continued use model.

$\mathrm{Xu}$ and Quaddus's ${ }^{34}$ pre- and post-adoption model of KMSs is unique, and is different from other IS adoption/diffusion models, which only deal with either pre-adoption stage or post-adoption stage. In the preadoption stage, it suggests that external influences, including individual difference factors, organizational factors, task complexity factors, and organic factors, will influence the adoption of knowledge management 
systems in an indirect way with their influence being mediated by the perceived benefits (usefulness) and

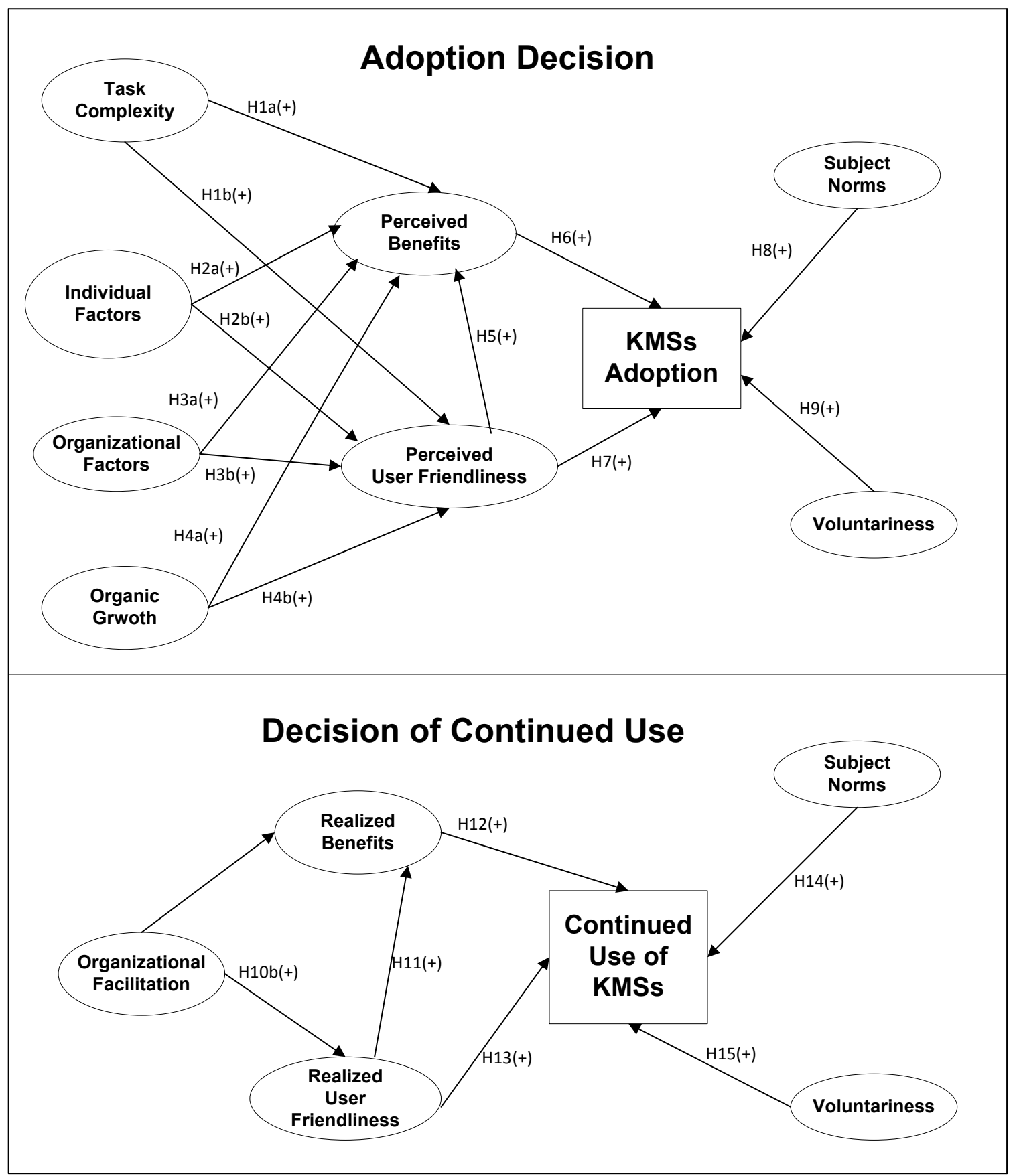

Fig. 1. Xu \& Quaddus' Model of Adoption and Continued Use of KMSs

perceived user friendliness (ease of use) of $\mathrm{KMSs}^{2,4,12,13,23,24,25,27,29,34}$. At the same time, the research model postulates that the perceived factors of perceived benefits, perceived user-friendliness (ease of use), 
subject norms (i.e., influence from people who are important to the user $^{4}$ ), and perceived voluntariness (i.e., the degree of voluntary use ${ }^{30}$ have direct effect on the adoption of KMSs. Also as per TAM ${ }^{12,13,14,15}$, perceived user friendliness affects perceived usefulness. In the post-adoption stage, it is suggested that organizational facilitation factors will influence the continued use of knowledge management systems in an indirect way with their influence being mediated by the realized benefits (usefulness) and realized user friendliness (ease of use) of $\mathrm{KMSs}^{2,4,12,13,23,24,25,27,29,34}$. At the same time, the research model postulates that realized benefits, realized user-friendliness (ease of use), subject norms, and voluntariness, have a direct effect on the continued use of KMSs. Also as per $\mathrm{TAM}^{12,13,14,15}$, realized user friendliness affects realized usefulness.

\section{The Research Model}

Using $\mathrm{Xu}$ and Quaddus's ${ }^{39}$ model as the basis, a research model of adoption and continued use of PCEHR system is developed. The research model (see Figure-2) includes two parts: (1) pre-adoption stage and post-adoption stage (see Figure-2).

In the pre-adoption stage, it suggests that the external factors including external environment \& influences, individual differences, and PCEHR system characteristics will influence the adoption of the PCEHR systems in an indirect way with their influence being mediated by the perceived benefits (usefulness) and perceived user friendliness (ease of use) of the system. At the same time, the research model postulates that perceived benefits, perceived user-friendliness (ease of use), subject norms, and perceived voluntariness have direct effect on the adoption of the PCEHR system, and it also indicates that perceived user friendliness affects perceived usefulness.

In the post-adoption stage, it is suggested that the facilitating factors will influence the continued use of the PCEHR system in an indirect way with their influence being mediated by the realized benefits(usefulness) and realized user friendliness (ease of use) of the system ${ }^{2,4,12,13,23,24,25,27,29,34}$. At the same time, the research model postulates that realized benefits, realized user-friendliness (ease of use), subject norms, and voluntariness have direct effect on the continued use of KMSs, and it also suggests realized user friendliness affects realized usefulness.

\subsection{External Factors \& Influences}

In the proposed research model, external factors and influences consist of variables of regulations and policies, ICT Infrastructure development, mobility, availability of computing equipment and popularity of mobile devices, affordability and accessibility of Internet services, economic uncertainty, continuity of the government, unified approach, and transparency and communication of NEHTA's operations (see Table-1). Table-1: External Factors and Influences

\begin{tabular}{|c|c|}
\hline $\begin{array}{l}\text { External Factors and } \\
\text { Influences }\end{array}$ & Brief Explanation \\
\hline Regulations and Policies & $\begin{array}{l}\text { The Australian government } \\
\text { has developed regulations } \\
\text { and policies relevant to the } \\
\text { PCEHR system (e.g., } \\
\text { Healthcare Identifiers Act } \\
\text { 2010, Personally Controlled } \\
\text { Electronic Health Records } \\
\text { Act 2012). }\end{array}$ \\
\hline $\begin{array}{l}\text { ICT Infrastructure } \\
\text { Development }\end{array}$ & $\begin{array}{l}\text { The deployment of national } \\
\text { broadband and investments } \\
\text { in e-heath infrastructure by } \\
\text { federal and state } \\
\text { governments have laid the } \\
\text { foundation for the } \\
\text { implementation of the } \\
\text { PCEHR system. }\end{array}$ \\
\hline Mobility & $\begin{array}{l}\text { The increasing mobility of } \\
\text { population from one place } \\
\text { to another needs accessible } \\
\text { e-health applications (such } \\
\text { as the PCEHR system) so } \\
\text { people can receive medical } \\
\text { treatment no matter where } \\
\text { they are. }\end{array}$ \\
\hline $\begin{array}{l}\text { Availability of Computing } \\
\text { Equipment and Popularity } \\
\text { of Mobile Devices }\end{array}$ & $\begin{array}{l}\text { The wide availability of } \\
\text { computing equipment and } \\
\text { the popularity of mobile } \\
\text { devices have made e-health } \\
\text { applications (such as the } \\
\text { PCEHR system) more } \\
\text { popular among Australian } \\
\text { consumers. }\end{array}$ \\
\hline $\begin{array}{l}\text { Affordability and } \\
\text { Accessibility of Internet } \\
\text { Services }\end{array}$ & $\begin{array}{l}\text { The high Internet } \\
\text { penetration in Australia } \\
\text { (more than } 85 \% \text { ), as a result } \\
\text { of good nationwide } \\
\text { technology infrastructure } \\
\text { and affordability, has made } \\
\text { e-health applications (such } \\
\text { as the PCEHR system) } \\
\text { more appealing among } \\
\text { Australian consumers. }\end{array}$ \\
\hline Economic Uncertainty & $\begin{array}{l}\text { The uncertainty of } \\
\text { Australian economy will } \\
\text { have impact on the future } \\
\text { development of the PCEHR } \\
\text { system and thus influence }\end{array}$ \\
\hline
\end{tabular}




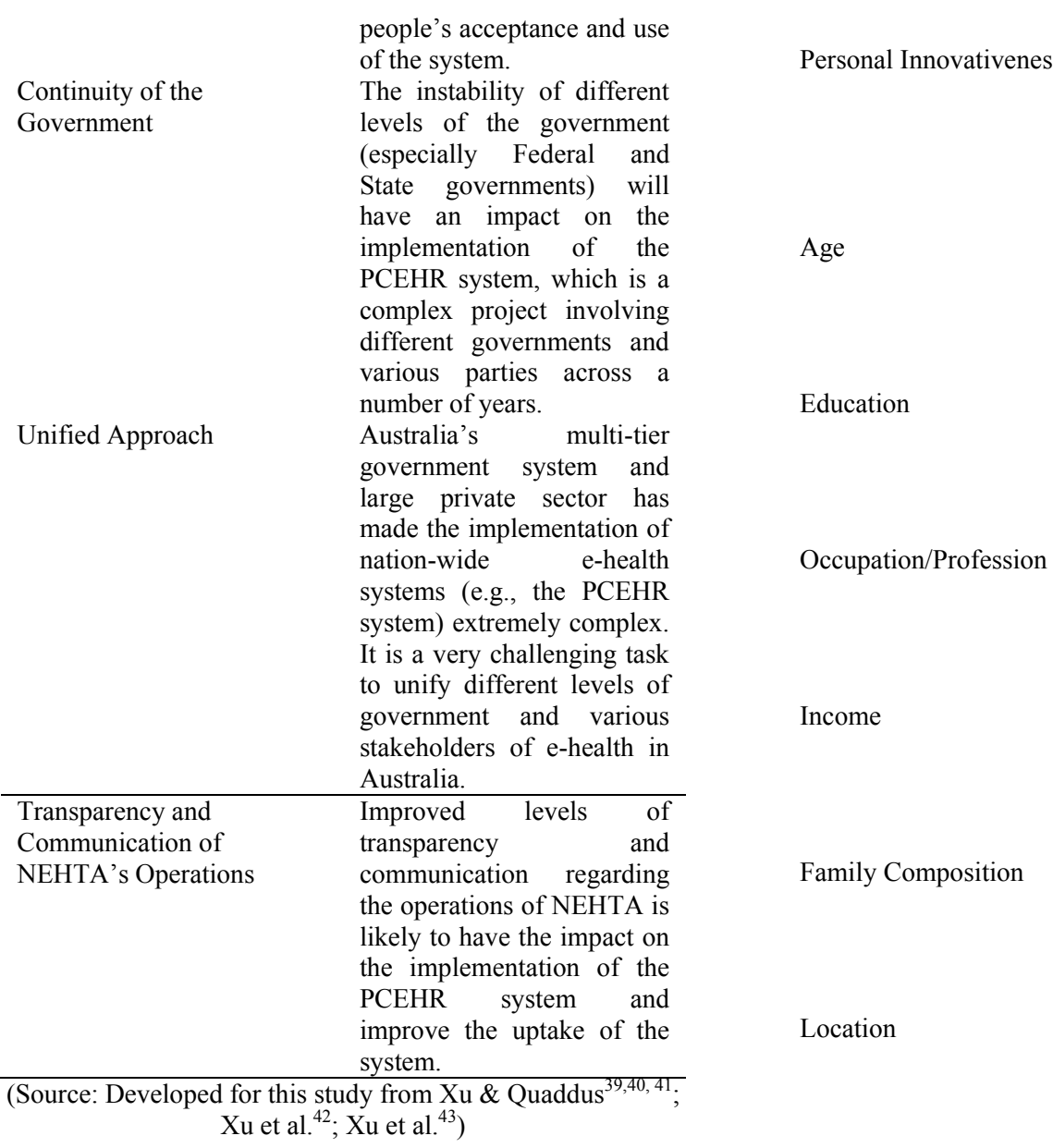

\subsection{Individual Differences}

Individual differences are represented by variables of involvement, experience/skill, personal innovativeness, age, education, occupation/profession, income, family composition, location, and attitude (see Table-2).

\section{Table-2: Individual Differences}

\begin{tabular}{|c|c|}
\hline Individual Differences & Brief Explanation \\
\hline Involvement & $\begin{array}{l}\text { Australian consumers' } \\
\text { involvement in the } \\
\text { deployment of the PCEHR } \\
\text { system would encourage } \\
\text { the ownership and lead to } \\
\text { the acceptance and use of } \\
\text { the system. }\end{array}$ \\
\hline Experience/Skill & $\begin{array}{l}\text { Australian consumers' } \\
\text { experience/skill in using } \\
\text { new systems and new } \\
\text { technologies will affect } \\
\text { their acceptance and use of } \\
\text { the PCEHR system. The } \\
\text { more experienced they are, } \\
\text { the more likely they would }\end{array}$ \\
\hline
\end{tabular}

accept and use the system. Australian consumers who are more innovative would be more likely to try new systems and new technologies (e.g., the PCEHR system).

Younger generation of Australian consumers could be more likely to accept and use the PCEHR system.

The education level of Australian consumers could have impact on their acceptance and use of the PCEHR system.

The occupation/profession of Australian consumers could have impact on their acceptance and use of the PCEHR system.

Australian consumers' income levels could have impact on their acceptance and use of the PCEHR system.

Family composition of Australian consumers could have impact on their acceptance and use of the PCEHR system.

Location of Australian consumers could have impact on their acceptance and use of the PCEHR system.

Attitude Australian consumers who don't feel comfortable and/or confident to manage and disseminate their medical information electronically are less likely to accept and use the PCEHR system.

(Source: Developed for this study from Xu \& Quaddus ${ }^{39,40,41}$; $\mathrm{Xu}$ et $\mathrm{al}^{42}$; Xu et $\mathrm{al}^{43}$ )

\subsection{PCEHR System Characteristics}

PCEHR system characteristics is represented by variables of trialability, accuracy, completeness, and currency of information, visibility and transparency, control, children medical information management, accessibility, availability, regional/district integration, cross-state integration, international integration, maintenance, and delegation (see Table-3). 
Table-3: PCEHR System Characteristics PCEHR System
Characteristics

Trialability

Accuracy, Completeness, and Currency of Information in the System

Visibility and Transparency

Control

Children

Medical Information Managemen

Accessibility

Availability

Regional/District Integration

Cross-State Integration

Integration

Delegation

\section{Brief Explanation}

Australian consumers could try out the PCEHR system before they decide to use the system.

Information in the PCEHR system is accurate, complete, and current.

Australian consumers are able to see all the activities in their PCEHR system accounts.

Australian consumers have full control of their medical information in the PCEHR system.

Australian consumers have full control of medical information of their children in the PCEHR system.

Australian consumer could access their electronic health records in the PCEHR system anywhere and anytime via different computing devices and channels.

The PCEHR system is available 24 hours, 365 days a year with very little and insignificant downtime.

The PCEHR system is integrated well with applications and systems of various health care providers across the region/district.

The PCEHR system is integrated well with applications and systems of various health care providers across the states.

The PCEHR system is integrated well with applications and systems of various health care providers outside Australia.

The PCEHR system is maintained and updated regularly.

The PCEHR system allows Australian consumers to delegate the management of their medical information in the system when necessary.

(Source: Developed for this study from Xu \& Quaddus ${ }^{39,40,41}$ $\mathrm{Xu}$ et $\mathrm{al}^{42}$; Xu et al. ${ }^{43}$ )

\subsection{Perceived Benefits}

Perceived benefits are represented by variables of personal medical information management, better and new services, efficiency/productivity, effectiveness, quality, safety, time \& cost reduction, continuity of health services, health/well-being, saving lives, and equitable access to health services (see Table-4).

\begin{tabular}{|c|c|}
\hline Perceived Benefits & Brief Explanation \\
\hline Personal & The PCEHR system would help \\
\hline $\begin{array}{l}\text { Information } \\
\text { Management }\end{array}$ & $\begin{array}{l}\text { Australian consumers better } \\
\text { manage their personal medical } \\
\text { information } \\
\text { electronically). }\end{array}$ \\
\hline Better and New Services & $\begin{array}{l}\text { The PCEHR system would help } \\
\text { create better and new health } \\
\text { services for Australian } \\
\text { consumers. }\end{array}$ \\
\hline Efficiency/Productivity & $\begin{array}{l}\text { The PCEHR system would help } \\
\text { enhance the } \\
\text { efficiency/productivity of health } \\
\text { services for Australian } \\
\text { consumers. }\end{array}$ \\
\hline Effectiveness & $\begin{array}{l}\text { The PCEHR system would help } \\
\text { improve the effectiveness of } \\
\text { health services for Australian } \\
\text { consumers. }\end{array}$ \\
\hline Quality & $\begin{array}{l}\text { The PCEHR system would help } \\
\text { improve the quality of health } \\
\text { services for Australian } \\
\text { consumers. }\end{array}$ \\
\hline Safety & $\begin{array}{l}\text { The PCEHR system would help } \\
\text { improve the safety of health } \\
\text { services for } \\
\text { consumers. }\end{array}$ \\
\hline Time \& Cost Reduction & $\begin{array}{l}\text { The PCEHR system would help } \\
\text { reduce time\& cost of health } \\
\text { services for } \text { Australian } \\
\text { consumers. }\end{array}$ \\
\hline $\begin{array}{l}\text { Continuity of Health } \\
\text { Services }\end{array}$ & $\begin{array}{l}\text { The PCEHR system would ensure } \\
\text { the continuity of health services } \\
\text { for Australian consumers. }\end{array}$ \\
\hline Health and Well-Being & $\begin{array}{l}\text { The PCEHR system would } \\
\text { improve the health/well-being of } \\
\text { Australian consumers. }\end{array}$ \\
\hline Saving Lives & $\begin{array}{l}\text { The PCEHR system would help } \\
\text { save lives. }\end{array}$ \\
\hline $\begin{array}{l}\text { Equitable Access to } \\
\text { Health Services }\end{array}$ & $\begin{array}{l}\text { The PCEHR system would help } \\
\text { provide equitable access to health }\end{array}$ \\
\hline & $\begin{array}{l}\text { services for } \\
\text { consumers. }\end{array}$ Australian \\
\hline
\end{tabular}

\subsection{Perceived User Friendliness}

Perceived user friendliness includes dimensions of simple to learn and use, affodable to learn and use, speed, privacy, human assistance and interaction, multi- 
channels and multiple touch points, and communities (see Table-5).

Table-5: Perceived User Friendliness

\begin{tabular}{|c|c|}
\hline $\begin{array}{ll}\text { Perceived } & \text { User } \\
\text { Friendliness } & \\
\end{array}$ & Brief Explanation \\
\hline Simple to Learn and Use & $\begin{array}{l}\text { The PCEHR system should } \\
\text { be simple to learn and use } \\
\text { with simple procedures. }\end{array}$ \\
\hline $\begin{array}{l}\text { Affordable to Learn and } \\
\text { Use }\end{array}$ & $\begin{array}{l}\text { The PCEHR system should } \\
\text { be affordable to learn and } \\
\text { use with simple procedures. }\end{array}$ \\
\hline Speed & $\begin{array}{l}\text { It should be fast to get the } \\
\text { required information in the } \\
\text { PCEHR system. }\end{array}$ \\
\hline Privacy & $\begin{array}{l}\text { The PCEHR system } \\
\text { effectively should address } \\
\text { the privacy concerns } \\
\text { associated with using the } \\
\text { system by establishing } \\
\text { privacy policies and } \\
\text { appropriate measures. }\end{array}$ \\
\hline Security & $\begin{array}{l}\text { The PCEHR system should } \\
\text { effectively address the } \\
\text { security concerns associated } \\
\text { with using the system by } \\
\text { establishing policies and } \\
\text { appropriate measures. }\end{array}$ \\
\hline $\begin{array}{l}\text { Human Assistance and } \\
\text { Interaction }\end{array}$ & $\begin{array}{l}\text { Australian consumers } \\
\text { should be provided with the } \\
\text { opportunities to } \\
\text { communicate with customer } \\
\text { service personnel when they } \\
\text { encounter issues with the } \\
\text { PCEHR system. }\end{array}$ \\
\hline $\begin{array}{l}\text { Multi-Channels } \\
\text { Communication } \\
\text { Multiple Touch Points }\end{array}$ & $\begin{array}{l}\text { Australian consumers } \\
\text { should be able to } \\
\text { communicate with the } \\
\text { operators of the PCEHR } \\
\text { system via multiple } \\
\text { channels and multiple touch } \\
\text { points. }\end{array}$ \\
\hline Communities & $\begin{array}{l}\text { Australian consumers } \\
\text { should be provided with the } \\
\text { opportunities to network } \\
\text { with other users of the } \\
\text { PCEHR system (online and } \\
\text { offline). }\end{array}$ \\
\hline
\end{tabular}

\subsection{Subject Norms on Adoption}

Subject norms on adoption include dimensions of peer pressure/influence, following early users' lead, respected people's influence, doctor's recommendation, and media influence (see Table-6).

Table-6: Subject Norms on Adoption

\begin{tabular}{ll}
\hline Subject Norms on Adoption & Brief Explanation \\
\hline Peer Pressure/Influence & $\begin{array}{l}\text { Peers have influence on } \\
\text { Australian consumers' }\end{array}$
\end{tabular}

acceptance and use of the PCEHR system.

Following Early Users' Lead Australian consumers would follow earlier users' lead in accepting and using the PCEHR system.

Respected People's Influence Australian consumers would accept and use the PCEHR system as a result of encouragement from respected people.

Doctor's Recommendation Australian consumers would accept and use the PCEHR system as a result of the recommendation from their doctors.

Media Influence Australian consumers would accept and use the PCEHR system as a result of the influence from media.

(Source: Developed for this study from Xu \& Quaddus ${ }^{39,40,41}$; $\mathrm{Xu}$ et al. ${ }^{42}$; Xu et al. ${ }^{43}$ )

\subsection{Voluntariness of Adoption}

Voluntariness of adoption includes dimensions of opt-in model and opt-out model (see Table-7).

Table-7: Voluntariness of Adoption

\begin{tabular}{ll}
\hline $\begin{array}{l}\text { Voluntariness } \\
\text { of Adoption }\end{array}$ & Brief Explanation \\
\hline Opt-in Model & $\begin{array}{l}\text { The current opt-in model for the } \\
\text { adoption of the PCEHR system would } \\
\text { make Australian consumers feel } \\
\text { comfortable. }\end{array}$ \\
\hline Opt-out Model & $\begin{array}{l}\text { The opt-out model for the adoption of } \\
\text { the PCEHR system would be more } \\
\text { effective for the adoption of the } \\
\text { PCEHR system among Australian } \\
\text { consumers. }\end{array}$ \\
\hline (Source: Developed for this study from Xu \& Quaddus ${ }^{39,40,41} ;$ \\
Xu et al. ${ }^{42} ;$ Xu et al. ${ }^{43}$ )
\end{tabular}

\subsection{PCEHR System Adoption}

PCEHR system adoption includes dimensions of uploading and storing information, disseminating and sharing information, and managing information (see Table-8).

Table-8: PCEHR System Adoption

PCEHR System Brief Explanation

Adoption

Uploading and Australian consumers will upload and Storing store their medical information into Information the PCEHR system.

Disseminating and Australian consumers will Sharing disseminate and share their medical Information information with various health service providers and government agencies via the PCEHR system. 


\section{Managing Australian consumers will use the Information PCEHR system to manage their medical information. \\ (Source: Developed for this study from Xu \& Quaddus ${ }^{39,40,41}$; $\mathrm{Xu}$ et al. ${ }^{42}$; Xu et al. ${ }^{43}$ )}

\subsection{Facilitating Factors}

Facilitating factors consist of incentives, imperatives, policy updates, system improvements, promotion of success stories and best practices, promotion of benefits, satisfying consumers' needs, and making use of the PCEHR system a part of the user's life (see Table-9).

\begin{tabular}{|c|c|}
\hline Facilitating Factors & Brief Explanation \\
\hline Incentives & $\begin{array}{l}\text { Appropriate incentives would } \\
\text { encourage Australian consumers to } \\
\text { continue their use of the PCEHR } \\
\text { system. }\end{array}$ \\
\hline Imperatives & $\begin{array}{l}\text { Appropriate imperatives would } \\
\text { encourage Australian consumers to } \\
\text { continue their use of the PCEHR } \\
\text { system. }\end{array}$ \\
\hline Policy Updates & $\begin{array}{l}\text { Appropriate policy updates } \\
\text { regarding the use of PCEHR } \\
\text { system would encourage Australian } \\
\text { consumers to continue their use of } \\
\text { the PCEHR system. }\end{array}$ \\
\hline $\begin{array}{l}\text { System } \\
\text { Improvements }\end{array}$ & $\begin{array}{l}\text { Continuous system improvements } \\
\text { would encourage Australian } \\
\text { consumers to continue their use of } \\
\text { the PCEHR system. }\end{array}$ \\
\hline $\begin{array}{l}\text { Promotion of } \\
\text { Success Stories and } \\
\text { Best Practices }\end{array}$ & $\begin{array}{l}\text { Through promoting success stories } \\
\text { and best practices of using the } \\
\text { PCEHR system, Australian } \\
\text { consumers will be encouraged to } \\
\text { continue their use of the system. }\end{array}$ \\
\hline $\begin{array}{l}\text { Promotion } \\
\text { Benefits }\end{array}$ & $\begin{array}{l}\text { Through promoting benefits of } \\
\text { using the PCEHR system, } \\
\text { Australian consumers will be } \\
\text { encouraged to continue their use of } \\
\text { the system. }\end{array}$ \\
\hline $\begin{array}{l}\text { Satisfying } \\
\text { Consumers' Needs } \\
\text { Continuously }\end{array}$ & $\begin{array}{l}\text { It should be ensured that the } \\
\text { PCEHR system can continuously } \\
\text { address Australian consumers } \\
\text { needs of their medical information. }\end{array}$ \\
\hline $\begin{array}{l}\text { Making Use of the } \\
\text { PCEHR System a }\end{array}$ & $\begin{array}{l}\text { Australian consumers should be } \\
\text { encouraged to make the use of the }\end{array}$ \\
\hline $\begin{array}{l}\text { Part of the User's } \\
\text { Life }\end{array}$ & em a part of their life. \\
\hline
\end{tabular}

\subsection{Realized Benefits}

Realized benefits are represented by variables of personal medical information management, better and new services, efficiency/productivity, effectiveness, quality, safety, time \& cost reduction, continuity of health services, health/well-being, saving lives, and equitable access to health services (see Table-10).

Table-10: Realized Benefits

\begin{tabular}{|c|c|}
\hline Realized Benefits & Brief Explanation \\
\hline $\begin{array}{l}\text { Personal Medical } \\
\text { Information Management }\end{array}$ & $\begin{array}{l}\text { The PCEHR system has } \\
\text { helped Australian } \\
\text { consumers better manage } \\
\text { their personal medical } \\
\text { information (especially } \\
\text { electronically). }\end{array}$ \\
\hline
\end{tabular}

Better and New Services The PCEHR system has helped create better and new health services for Australian consumers.

Efficiency/Productivity The PCEHR system has helped enhance the efficiency/productivity of health services for Australian consumers.

Effectiveness The PCEHR system has helped improve the effectiveness of health services for Australian consumers.

Quality The PCEHR system has helped improve the quality of health services for Australian consumers.

Safety The PCEHR system has helped improve the safety of health services for Australian consumers.

Time \& Cost Reduction The PCEHR system has helped reduce time\& cost of health services for Australian consumers.

Continuity of Health The PCEHR system Services has ensured the continuity of health services for Australian consumers.

Health and Well-Being The PCEHR system has improved the health/wellbeing of Australian consumers.

Saving Lives The PCEHR system has helped save lives.

Equitable Access to Health The PCEHR system has Services helped provide equitable access to health services for Australian consumers.

(Source: Developed for this study from Xu \& Quaddus ${ }^{39,40,41}$; $\mathrm{Xu}$ et al. ${ }^{42}$; Xu et al. ${ }^{43}$ )

\subsection{Realized User Friendliness}

Realized user friendliness includes dimensions of simple to learn and use, cheap to learn and use, speed, privacy, human assistance and interaction, multichannels and multiple touch points, and communities (see Table-11). 
Table-11: Realized User Friendliness

\begin{tabular}{|c|c|}
\hline Realized User Friendliness & Brief Explanation \\
\hline Simple to Learn and Use & $\begin{array}{l}\text { The PCEHR system is } \\
\text { simple to learn and use with } \\
\text { simple procedures. }\end{array}$ \\
\hline Cheap to Learn and Use & $\begin{array}{l}\text { The PCEHR system is } \\
\text { cheap to learn and use with } \\
\text { simple procedures. }\end{array}$ \\
\hline Speed & $\begin{array}{l}\text { It is fast to get the required } \\
\text { information in the PCEHR } \\
\text { system. }\end{array}$ \\
\hline Privacy & $\begin{array}{l}\text { The PCEHR system } \\
\text { effectively addresses the } \\
\text { privacy concerns associated } \\
\text { with using the system by } \\
\text { establishing privacy policies } \\
\text { and appropriate measures. }\end{array}$ \\
\hline Security & $\begin{array}{l}\text { The PCEHR system } \\
\text { effectively addresses the } \\
\text { security concerns associated } \\
\text { with using the system by } \\
\text { establishing policies and } \\
\text { appropriate measures. }\end{array}$ \\
\hline $\begin{array}{l}\text { Human Assistance and } \\
\text { Interaction }\end{array}$ & $\begin{array}{l}\begin{array}{l}\text { Australian consumers are } \\
\text { provided with the } \\
\text { opportunities }\end{array} \\
\text { communicate with human } \\
\text { beings when they have } \\
\text { issues with the PCEHR } \\
\text { system. }\end{array}$ \\
\hline $\begin{array}{l}\text { Multi-Channels } \\
\text { Communication and } \\
\text { Multiple Touch Points }\end{array}$ & $\begin{array}{l}\text { Australian consumers are } \\
\text { able to communicate with } \\
\text { the operators of the PCEHR } \\
\text { system via multiple } \\
\text { channels and multiple touch } \\
\text { points. }\end{array}$ \\
\hline Communities & $\begin{array}{l}\text { Australian consumers are } \\
\text { provided with the } \\
\text { opportunities to network } \\
\text { with other users of the } \\
\text { PCEHR system (online } \\
\text { and/or offline). }\end{array}$ \\
\hline
\end{tabular}

\subsection{Subject Norms on Continued Use}

Subject norms on continued use includes dimensions of peer pressure/influence, following early users' lead, respected people's influence, doctor's recommendation, and media influence (see Table-12).

Table-12: Subject Norms on Continued Use

\begin{tabular}{ll}
\hline Subject Norms on Adoption & Brief Explanation \\
\hline Peer Pressure/Influence & $\begin{array}{l}\text { Peers have influence on } \\
\text { Australian consumers' } \\
\text { continued use of the } \\
\text { PCEHR system. } \\
\text { Following Early Users' Lead } \\
\text { would follow earlier users' } \\
\text { lead in continued use the }\end{array}$
\end{tabular}

\author{
PCEHR system. \\ Respected People's Influence Australian consumers \\ would continually use the \\ PCEHR system as a result \\ of encouragement from \\ respected people. \\ Doctor's Recommendation Australian consumers \\ would continually use the \\ PCEHR system as a result \\ of the recommendation \\ from their doctors. \\ Media Influence \\ Australian consumers \\ would continually use the \\ PCEHR system as a result \\ of the influence from \\ media. \\ (Source: Developed for this study from Xu \& Quaddus ${ }^{39,40,41}$; \\ $\mathrm{Xu}$ et al. ${ }^{42}$; Xu et al. ${ }^{43}$ )
}

\subsection{Voluntariness of Continued Use}

Voluntariness of continued use includes dimensions of opt-in model and opt-out model (see Table-13).

Table-13: Voluntariness of Continued Use

\begin{tabular}{ll}
\hline $\begin{array}{l}\text { Voluntariness of } \\
\text { Adoption }\end{array}$ & Brief Explanation \\
\hline Opt-in Model & $\begin{array}{l}\text { The current opt-in model for the use of } \\
\text { the PCERH system would encourage } \\
\text { Australian consumers to continually use } \\
\text { the system. }\end{array}$ \\
\hline Opt-out Model & $\begin{array}{l}\text { The opt-out model for the use of the } \\
\text { PCERH system would be more effective } \\
\text { for the continued use of the PCEHR } \\
\text { system among Australian consumers. }\end{array}$ \\
\hline (Source: Developed for this study from Xu \& Quaddus ${ }^{39,40,41} ;$ \\
Xu et al. ${ }^{42} ;$ Xu et al ${ }^{43}$ )
\end{tabular}

\subsection{Continued Use of PCEHR System}

Continued use of PCEHR system includes dimensions of uploading and storing information, disseminating and sharing information, and managing information (see Table-14).

Table-14: Continued Use of the PCEHR System

\begin{tabular}{ll}
\hline $\begin{array}{l}\text { PCEHR System } \\
\text { Adoption }\end{array}$ & Brief Explanation \\
\hline $\begin{array}{l}\text { Uploading and } \\
\text { Storing }\end{array}$ & $\begin{array}{l}\text { Australian consumers will continually } \\
\text { upload and store their medical }\end{array}$ \\
$\begin{array}{l}\text { Information } \\
\text { Disseminating } \\
\text { and Sharmation into the PCEHR system. }\end{array}$ & $\begin{array}{l}\text { Australian consumers will continually } \\
\text { disseminate and share their medical } \\
\text { Information }\end{array}$ \\
$\begin{array}{l}\text { information with various health } \\
\text { service providers and government } \\
\text { agencies via the PCEHR system. }\end{array}$ \\
$\begin{array}{l}\text { Australian consumers will continually } \\
\text { use the PCEHR system to manage } \\
\text { theing medical information. }\end{array}$ \\
\hline (Source: Developed for this study from Xu \& Quaddus ${ }^{39,40,41} ;$ \\
Xu et al. ${ }^{42} ;$ Xu et al. ${ }^{43}$ )
\end{tabular}




\section{Hypotheses Development}

Past studies (such as Grover ${ }^{20}$; Premkumar, Ramamurthy \& Crum $1997^{32}$; Rai \& Bajwa ${ }^{33}$; Sarvary $^{35}$; $\mathrm{Xu} \&$ Quaddus $^{40}$; Xu et $\mathrm{al}^{42}$; $\mathrm{Xu}$ et $\mathrm{al}^{43}$ ) report environmental factors are associated with the adoption of innovation. In addition, Davis's ${ }^{12}$ technology acceptance model proposes that external factors, such as external factors \& influences, will influence PCEHR system adoption by affecting perceived benefits and perceived user friendliness. The preceding discussion leads to the following hypothesis:

Hypothesis 1a: “External Factors \& Influences” positively influence the "Perceived Benefits" of the PCEHR System.

Hypothesis 1b: “External Factors \& Influences” positively influence the "Perceived User Friendliness" of the PCEHR System.

Individual differences have been found important in explaining the acceptance and successful implementation of information systems ${ }^{24}$. Past research (such as Zmud ${ }^{44}$; Brancheau \& Wetherbe ${ }^{9}$; Rogers ${ }^{34}$; Gefen \& Straub $^{18}$; Agarwal \& Prasad $^{2}$; Venkatesh, Morris \& Ackerman ${ }^{38}$; Agarwal \& Prasad $^{3} ; \mathrm{Xu} \&$ Quaddus $^{39}$; Xu \& Quaddus ${ }^{40}$; Xu et al. ${ }^{42}$; Xu et al. ${ }^{43}$ ) has indicated that the individual/end user characteristics/differences are important factors in explaining/predicting the adoption of innovations. In addition, Davis ${ }^{12}$ technology acceptance model proposes that external factors, such as individual factors, will influence PCEHR system adoption by affecting perceived benefits and perceived user friendliness. The PCEHR system is only successful if the users of the system succeed with the system. Australian consumers' acceptance and use of the system is critical to the success of the system. Hence, it is hypothesised that:

Hypothesis 2a: "Individual factors" positively influence the "Perceived Benefits" of the PCEHR system.

Hypothesis 2b: “Individual factors" positively influence the "Perceived User Friendliness" of the PCEHR system.

Past studies (such as Kwon \& $\mathrm{Zmud}^{26}$; Davis, Bagozzi \& Warshaw ${ }^{16}$; Rogers $^{34}$; Moore $^{30}$; Igbaria, Gumaraes \& Davis24; Chau \& Tam11; Beatty, Shim \& Jones $^{7}$, Hong et $\mathrm{al}^{21}, \mathrm{Xu} \&$ Quaddus $^{39}, \mathrm{Xu} \&$ Quaddus $^{40}, \mathrm{Xu} \&$ Quaddus $^{42}$; Xu et al. $^{43}$ ) indicate the importance of the innovation/system characteristics in the adoption and diffusion of innovation. In addition, Davis's ${ }^{12}$ technology acceptance model proposes that external factors, such as PCEHR system characteristics, will influence adoption of the system by affecting perceived benefits and perceived user friendliness. The above discussions lead to the following hypothesis: Hypothesis 3a: "PCEHR System Characteristics" positively influence the "Perceived Benefits" of the PCEHR System.

Hypothesis 3b: PCEHR System Characteristics” positively influence the "Perceived User Friendliness" of the PCEHR System.

TAM $^{12,13,14,15}$ and other related studies (such as Adams, Nelson \& Todd ${ }^{1}$; Igbaria, Guimaraes \& Davis ${ }^{24}$; Igbaria et al. $^{25}$; Venkatesh \& Davis ${ }^{38}$; Xu \& Quaddus ${ }^{39}$ ) have identified perceived user friendliness as an important determinant of system acceptance and use via perceived benefits and a causal determinant of perceived benefits. Perceived user friendliness has a direct and positive impact on perceived benefits. Therefore the following hypotheses are proposed: Hypothesis 4: "Perceived User Friendliness" of PCEHR System positively influences the "Perceived Benefits" of the PCEHR System.

Hypothesis 10: "Realized User Friendliness" of PCEHR System positively influences the "Realized Benefits" of the PCEHR System.

The theory of diffusion of innovation ${ }^{34}$, the theory of reasoned action ${ }^{4}$, and the technology acceptance model $^{12}$ all propose direct impacts of perceptions on intention to use the system. Meanwhile Bansler and $\operatorname{Havn}^{6}$ suggest that expectations/perceptions are key factors in determining organization's and individual's decision about whether or not to adopt a new knowledge management system. Furthermore Bhattacherjee ${ }^{8}$ find that users' confirmation of their initial use of information systems has a positive impact on their intention of continued use of the systems. As a result, it is proposed that perceived benefits and perceived user friendliness have a direct impact on PCEHR system adoption. As per the above discussions, it is hypothesised that:

Hypothesis 5: "Perceived Benefits" of PCEHR System positively influence the "Adoption" of the PCEHR System.

Hypothesis 6: "Perceived User Friendliness" of PCEHR System positively influence the "Adoption" of the PCEHR System.

Hypothesis 11: “Realized Benefits” of PCEHR System positively influence the "Continued Use" of the PCEHR System. 
Hypothesis 12: "Realized User Friendliness" of PCEHR System positively influence the "Continued Use" of the PCEHR System.

Subject norms describe the social influence that may affect a person's intention to use knowledge management systems. People often take action based on their perceptions of what others think they should do. Literature (such as Thompson, Higgins \& Howell ${ }^{36}$; Liker \& Sindi ${ }^{27}$; Lucas \& Spitler $^{28}$, Xu \& Quaddus ${ }^{39}$ ) has found that subject norms are positively associated with individual's acceptance of new technology. Huber $^{22}$ suggest that there is considerable ignorance in the literature on the impacts of the social-psychological forces such as the need to adhere to social norms, the need to comply with organizational norms (the right thing to do), the need for recognition, on knowledge sharing and participation in the knowledge management systems. Gray ${ }^{19}$ suggests that use of knowledge management systems may be a self-reinforcing process. Once the value of such system is established, the system use is likely to become routine and thus lead to widespread acceptance and use. The above discussions results in the following hypotheses:

Hypothesis 7: "Subject Norms" have positively influence impact on the "Adoption" of the PCEHR System.

Hypothesis 13: "Subject Norms" have positively influence impact on the "Continued Use" of the PCEHR System.

Voluntariness focuses on consumers' voluntary adoption and use of PCEHR system. In the past, research (such as Bansler \& Havn; ${ }^{6} \mathrm{Xu} \&$ Quaddus $^{39}$ ) has suggested that voluntary-basis approach has a positive impact on people's decision to adopt and use innovations/new systems. The current opt-in model is not working well, and it is argued that the opt-out model should be adopted to increase the adoption rate of the PCEHR system ( $\mathrm{Xu}$ et $\mathrm{al}^{42}$; $\mathrm{Xu}$ et $\mathrm{al}^{43}$ ). The above discussions lead to the following hypotheses:

Hypothesis 8: "Voluntary use" of PCEHR System negatively influences the "Adoption" of the PCEHR System.

Hypothesis 14: “Voluntary use" of PCEHR System negatively influences the "Continued Use" of the PCEHR System.

Government faces the challenge of how to ensure consumers' sustained use of PCEHR system after their adoption of the system. Sustained/continued use of PCEHR system means that use of the system has become a part of consumers' life. By providing facilitating measures (such as incentives, imperatives, policy updates, system improvements, promotion of success stories and best practices, promotion of benefits, satisfying consumers' needs, and making use of the PCEHR system as a part of the user's life), governments could developed consumers' positive attitude to and perceptions of the system and thus lead to their continued use of the system. In addition, the theory of diffusion of innovations ${ }^{34}$, the theory of reasoned action $^{4}$, and the technology acceptance model ${ }^{12}$ all propose direct impacts of perceptions on intention to use the systems. As a result, it is proposed that perceived benefits and perceived user friendliness have a direct impact on continued use of the PCEHR system. The above discussions results in the following hypotheses:

Hypothesis 10a: "Facilitating Factors" positively influence the "Realized Benefits" of the PCEHR System.

Hypothesis 10b: “Facilitating Factors" positively influence the "Realized User Friendliness" of the PCEHR System.

\section{Conclusion and Future Directions}

As far as the researchers are aware, the developed model of adoption and continued use of the PCEHR system will be the first one on accessing and improving the implementation of the PCEHR system in Australia. Identified factors and variables of the tested model will assist in understanding challenges and issues associated with the continuous development and implementation of the system and serve as guidelines to the successful implementation of the system. In addition, the outcomes of this research will make a contribution to the improvement of the awareness of the system among Australian consumers and will result in economic, environmental and social benefits to the Australian community. The immediate next step is to develop a survey questionnaire, based on the research model and some field studies examining any new factors and variables, refine the developed questionnaire via a pilot survey, and test the final questionnaire via a national survey of consumers in Australia. The future research also could look at developing and testing a model of adoption and continued use of the PCEHR system among health services providers. 


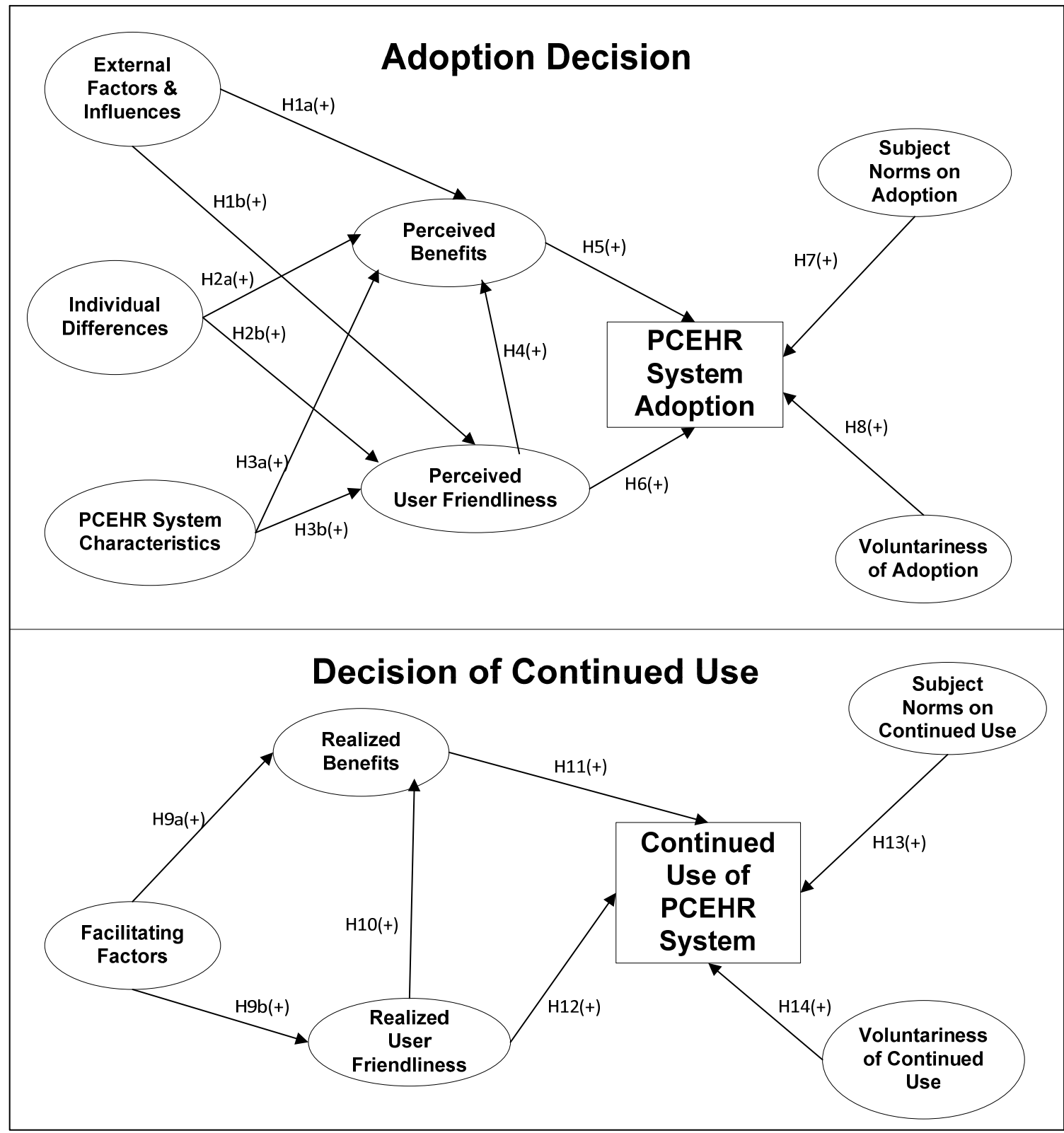

Fig. 2. The Model of Consumers' Adoption and Continued Use of the PCEHR System

\section{References}

[1] Adams, D.A., Nelson, R.P. \& Todd, P.A. 1992, 'Perceived usefulness, ease of use, and usage of information technology: a replication', MIS Quarterly, vol. 16 , no. 2 , pp. 227-247.

[2] Agarwal, R. \& Prased, J. 1999, 'Are Individual Differences Germane to the Acceptance of New Information Technologies', Decision Sciences, vol. 30, no. 2, pp. 361-391. 
[3] Agarwal , R. \& Prasad, J. 2000, 'A field study of the adoption of software process innovations by information systems professionals', IEEE Transaction on Engineering Management, vol. 47, no. 3, pp. 295-308.

[4] Ajzen, I. \& Fishbein, M. 1980, Understanding Attitudes and Predicting Social Behavior, Prentice-Hall, Inc., Englewood Cliffs, New Jersey 07632.

[5] Australian Nursing Journal 2011, 'News: National Ehealth rollout on', Australian Nursing Journal, vol. 18, no. 10, p.5.

[6] Bansler, J.P. \& Havn, E. 2002, 'Exploring the role of networks in IT implementation-The case of knowledge management systems', The Xth European Conference on Information Systems, Gdansk, Poland, June 2002.

[7] Beatty, R.C., Shim, J. P., \& Jones, M.C. 2001, 'Factors influencing corporate website adoption: a time-based assessment', Information \& Management, vol. 38, no. 6, pp. 337-354.

[8] Bhattacherjee, A. 2001, 'Understanding Information Systems Continuance: An Expectation-Confirmation Model', MIS Quarterly, Vol. 25, No. 3, pp. 351-370.

[9] Brancheau, J. C. \& Wetherbe, J. C. 1990, 'The adoption of spreadsheet software: testing innovation diffusion theory in the context of end-user computing', Information Systems Research, vol. 1, no. 2, pp. 123-139.

[10] Burmester, S. 2012, Review the Progress of eHealth in Australia, Presentation by National E-Health Transition Authority, 20/03/2012.

[11] Chau, P. Y. K. \& Tam, K. Y. 1997, 'Factors affecting the adoption of open systems: An exploratory study', MIS Quarterly, vol. 21, no. 1, pp. 1-24.

[12] Davis, F. D. 1986, A technology Acceptance Model for Empirically Testing New End-User Information Systems: Theory and Results, Doctoral Dissertation, Massachusetts Institute of Technology.

[13] Davis, F. D. 1989, 'Perceived usefulness, perceived ease of use, and user acceptance of information technology', MIS Quarterly, vol. 13, no. 3, pp. 319-340.

[14] Davis, F. D. 1993, 'User acceptance of information technology: System characteristics, user perception and behavioural impacts', International Journal of ManMachine Studies, Vol. 38, pp. 475-487.

[15] Davis, F. D., Bagozzi, R. P. \& Warshaw, P. R. 1989, "User acceptance of computer technology: a comparison of two theoretical models", Management Science, vol. 35, no. 8, pp. 982-1002.

[16] Davis, F. D., Bagozzi, R. P. \& Warshaw, P. R. 1992, 'Extrinsic and intrinsic motivation to use computers in the workplace," Journal of Applied Social Psychology, vol. 22, no. 14, pp. 1111-1132.

[17] Department of Health and Ageing 2012, Expected Benefits of the National PCEHR System, May 2012.
[18] Gefen, D. \& Straub, D. W. 1997, 'Gender differences in the perceptions and use of E-mail: an extension to the technology acceptance model', MIS Quarterly, vol. 21, no. 4 , pp. 389-400.

[19] Gray, P. H. 2000, 'The effects of knowledge management systems on emergent teams: towards a research model', Journal of Strategic Information Systems, vol 9, no. 2-3, pp. 175-191.

[20] Grover, V. 1993, 'An empirically derived model for the adoption of customer-based interorganizational systems', Decision Sciences, vol. 24, no. 3, pp. 603-640.

[21] Hong, W.Y., Thong, J. Y. L., Wong, W.W. \& Tam, K. Y. 2002, 'Determinants of user acceptance of digital libraries: an empirical examination of individual differences and system characteristics', Journal of Management Information Systems, vol. 18, no. 3, pp. 97124.

[22] Huber, G. P. 2001, 'Transfer of knowledge in knowledge management systems: unexplored issues and suggested studies', European Journal of Information Systems, vol. 10, no. 2, pp. 72-79.

[23] Igbaria, M. 1994, 'An examination of the factors contributing to microcomputer technology acceptance', Accounting, Management \& Information Technology, vol. 4, no. 4, pp. 205-224.

[24] Igbaria, M., Guimaraes, T. \& Davis, G.B. 1995, 'Testing the determinants of microcomputer usage via a structural equation model', Journal of Management Information Systems, vol. 11, no. 4, pp. 87-114.

[25] Igbaria, M., Zinatelli, N., Cargg, P. \& Cavaye, A. L. M. 1997, 'Personal Computing Acceptance Factors in Small Firms: A Structural Equation Model', MIS Quarterly, vol. 21, no. 3, pp. 279-302.

[26] Kwon, T. H. \& Zmud, R. W. 1987, 'Unifying the fragment models of information systems implementation' in Critical Issues in Information System Research, eds R. J. Boland Jr. \& R. A. Hirscheim, John Wiley \& Sons, New York, pp. 227-251.

[27] Liker, J. K. \& Sindi, A. A. 1997, 'User acceptance of expert systems: A test of the theory of reasoned action', Journal of Engineering and Technology Management, vol. 14, no. 2, pp. 147-173.

[28] Lucas, H. C. \& Spitler, V. K. 1999, 'Technology use and performance: a field study of broker workstations', Decision Sciences, vol. 30, no. 2, pp. 291-311.

[29] Moore, G. C. 1987, 'End-user computing and office automation: a diffusion of innovation perspectives', INFOR, vol. 25, no. 3, pp. 214-235.

[30] Moore, G. C. \& Benbasat, I. 1991, 'Development of an instrument to measure the perceptions of adopting an information technology innovation', Information System Research, vol. 2, no. 3, pp. 192-222. 
[31] NETHA 2012, Overview of the National eHealth Strategy and the Personally Controlled Electronic Health Record, May 2012.

[32] Premkumar G, Ramamurthy, K. \& Crum, M. 1997, 'Determinants of EDI adoption in the transportation industry", European Journal of Information Systems, vol. 6, no. 2, pp. 107-121.

[33] Rai, A. \& Bajwa, D. 1997, 'An empirical investigation into factors relating to the adoption of executive information systems: an analysis of EIS for collaboration and decision support', Decisions Sciences, vol. 28, no. 4, pp. 939-974.

[34] Rogers, E. M. 1995, Diffusion of Innovations, Fourth Edition, The Free Press, New York, USA.

[35] Sarvary, M. (1999) "Knowledge Management and Competition in the Consulting Industry", California Management Review, vol. 41, no.2, pp.95-107.

[36] Thompson, R. L., Higgins, C. A. \& Howell, J. M. 1991, 'Personal computing: toward a conceptual model of utilization', MIS Quarterly, vol. 15, no. 1, pp. 125-143.

[37] Townsend, R. 2012, 'Doctors and patients uneasy about new e-health record system', The Conversation, July 05/07/2012.

[38] Venkatesh, V. \& Davis, F. D. 2000, 'A theoretical extension of the technology acceptance model: four longitudinal field studies', Management Science, vol. 46, no. 2, pp. 186-204

[39] Xu, J. \& Quaddus, M. 2007, 'Exploring the Factors Influencing End Users' Acceptance of Knowledge Management Systems: Development of a Research Model of Adoption and Continued Use', Journal of Organizational and End-Users Computing, vol. 19, no.4, pp. 57-79.

[40] Xu. J. \& Quaddus, M. 2009 ed., E-Business in the 21st Century: Realities, Challenges, and Outlook, World Scientific, Singapore.

[41] Xu. J. \& Quaddus, M. 2012, "Examining a Model of Knowledge Management Systems Adoption and Diffusion: a Partial Least Square Approach", Journal of Knowledge-based Systems, Vol. 27, pp. 18-28.

[42] Xu, J., Gao, X. Z., Sorwar, G. \& Croll, P. 2012, "Current Status, Challenges, and Outlook of E-Health Record Systems in Australia", 7th International Conference on Intelligence Systems and Knowledge Engineering, Dec 15-17, 2012, Beijing, China.

[43] Xu, J., Gao, X. J., Sorwar, G. \& Croll, P. 2013, "Implementation of E-Health Record Systems in Australia", International Technology Management Review, Vol. 3, No.2, pp. 92-104.

[44] Zmud, R. W. 1979, 'Individual differences and MIS success: a review of the empirical literature', Management Science, vol. 25, no. 10, pp. 966-979. 